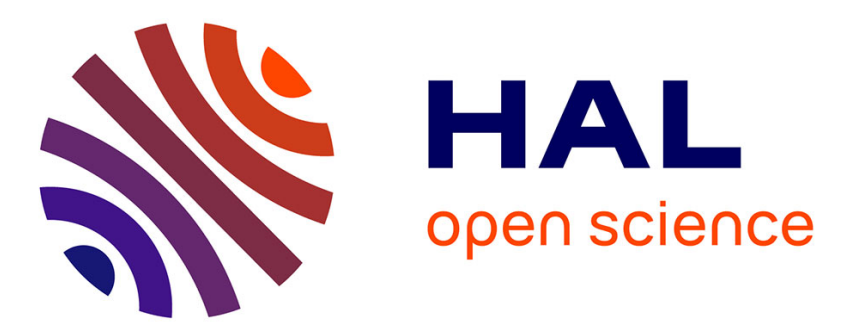

\title{
The use of off-farm habitats by foraging bumblebees in agricultural landscapes: implications for conservation management
}

\author{
Lynne Osgathorpe, Kirsty Park, Dave Goulson
}

\section{To cite this version:}

Lynne Osgathorpe, Kirsty Park, Dave Goulson. The use of off-farm habitats by foraging bumblebees in agricultural landscapes: implications for conservation management. Apidologie, 2012, 43 (2), pp.113127. 10.1007/s13592-011-0083-z . hal-01003621

\section{HAL Id: hal-01003621 \\ https://hal.science/hal-01003621}

Submitted on 1 Jan 2012

HAL is a multi-disciplinary open access archive for the deposit and dissemination of scientific research documents, whether they are published or not. The documents may come from teaching and research institutions in France or abroad, or from public or private research centers.
L'archive ouverte pluridisciplinaire HAL, est destinée au dépôt et à la diffusion de documents scientifiques de niveau recherche, publiés ou non, émanant des établissements d'enseignement et de recherche français ou étrangers, des laboratoires publics ou privés. 


\title{
The use of off-farm habitats by foraging bumblebees in agricultural landscapes: implications for conservation management
}

\author{
Lynne M. Osgathorpe ${ }^{2}$, Kirsty PARK ${ }^{1}$, Dave Goulson ${ }^{1}$ \\ ${ }^{1}$ School of Biological and Environmental Sciences, University of Stirling, Stirling FK9 4LA, UK \\ ${ }^{2}$ School of Biological Sciences, University of Bristol, Woodland Road, Bristol BS8 1UG, UK
}

Received 15 October 2010 - Revised 16 March 2011 - Accepted 29 March 2011

\begin{abstract}
Recent studies have focused on ways to enhance floral availability on arable farmland, but little attention has been paid to the importance of off-farm habitats in providing forage for pollinators within farmed landscapes. We conducted a comparative study to assess bumblebees and flower abundance on farmed and offfarm habitats in two low-intensity systems in the UK, the Somerset Levels and the Outer Hebrides. In both farming systems, both on- and off-farm habitats contributed to the mosaic of bumblebee forage. In the Somerset Levels, track edges and road verges were particularly important sources of forage for long-tongued bumblebees. Cattle-grazed pasture in Somerset and winter-grazed pasture in the Outer Hebrides were also notable sources of bumblebee forage. Non-agricultural habitats need to be integrated into local land management plans to ensure the provision of forage for bumblebees throughout the breeding season.
\end{abstract}

\section{Bombus / foraging / habitat use / road verge / grazing}

\section{INTRODUCTION}

Agricultural intensification has resulted in declines of many species of flora and fauna, particularly habitat specialists (Robinson and Sutherland 2002). Consequently, many species now found in farmland habitats are generalists that have been able to adapt to the changes in environmental conditions (Robinson and Sutherland 2002; Goulson et al. 2005, 2006). Of the 25 bumblebee species native to Britain, three are now extinct and six others are formally listed as being threatened (Benton 2006; Goulson et al. 2008a, b). As relatively long-range foragers they are able to utilise a wide range of different foraging habitats, therefore landscape context as well as heterogeneity are important factors influencing their abundance

Corresponding author: L.M. Osgathorpe, lynne.osgathorpe@bristol.ac.uk Manuscript editor: Marla Spivak and richness in agricultural areas (Rundlöf et al. 2008). Bumblebees are most commonly associated with wildflower rich semi-natural grasslands and heathland habitats (Goulson 2003; Williams and Osborne 2009). However, vast areas of these seminatural habitats have been lost over the past century following changes to agricultural practices (Pywell et al. 2005; Carvell et al. 2006; Chamberlain et al. 2000; Stoate et al. 2001). Consequently, the rarest bumblebees are now confined to isolated areas that have not received the high levels of agricultural intensification experienced elsewhere in the UK (Goulson et al. 2006). Two examples of such areas within the UK are the crofting systems found in northwest Scotland and the Somerset Levels in southwest England.

Agriculture in crofting areas traditionally operates on a small scale, with few artificial inputs. Traditional crofting practices include areas of 
lowland grassland grazed during the winter months and livestock relocated to moorland grazing during the summer. Consequently, crofted areas can provide suitable habitats for many species that are rare elsewhere in the UK (e.g. corncrake [Crex crex], northern colletes bee [Colletes floralis]; Love 2003). The flower rich machair grasslands found along the west coast of the Outer Hebrides in Scotland are particularly important, providing floral resources for a wide range of invertebrates including Bombus distinguendus and Bombus muscorum (Goulson et al. 2005; Benton 2006).

The Somerset Levels and Moors Environmentally Sensitive Area (ESA) covers over 27,000 ha of central Somerset and is characterised by low-lying, traditionally managed wet and open grassland bounded by drainage ditches ('rhynes') and bisected by trackways, locally known as 'droves' (Natural England 2010). The grassland landscape consists of species rich meadows and pastures (Natural England 2010), which provide foraging habitats for at least 15 species of bumblebee, including the rare Bombus sylvarum and Bombus ruderarius (Benton 2006). Agriculture is typified by beef and dairy farming, although under the former ESA scheme management restrictions were imposed to preserve the ecological integrity of the region.

Traditionally both these agricultural systems provide essential grassland foraging habitats for bumblebees and internationally important habitats for many other taxa (Love 2003; Natural England 2010). The value of non-agricultural habitats, such as road verges and tracks, to invertebrates in farmed landscapes has been examined by several authors (e.g. Croxton et al. 2002; Hopwood 2008; Noordijk et al. 2009). In less intensively managed farmland areas of Estonia, greater bumblebee densities were recorded foraging on these off-farm habitats compared to farmed habitats (Mänd et al. 2002). Redpath et al. (2010) provide anecdotal evidence of the use of such habitats by foraging bumblebees in crofted areas and suggest that these may be of importance in supporting bumblebee populations in the Outer Hebrides, Scotland. In this paper, we conduct a comparative study to assess the value of farmed and off-farm habitats in providing forage for bumblebees in two lowintensity agricultural systems in the UK: a crofting system threatened by intensification in the Outer Hebrides and a low-intensity system in the Somerset Levels.

\section{METHODS}

\subsection{Study sites}

We conducted our study in the Outer Hebrides and the Somerset Levels in two consecutive years to enable us compare the importance of farm versus off-farm habitats for bumblebees. In 2009, fieldwork was undertaken on the island of North Uist in the Outer Hebrides. Survey work focused on the habitats surrounding the crofting townships of Balranald, Hougharry and Tigharry in the northwest of

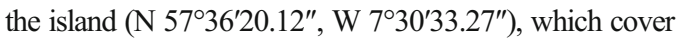
an area of approximately $5 \mathrm{~km}^{2}$. Within this area, six different habitats were identified which included all of the major habitats present: silage, fallow, summer-grazed pasture (mixed livestock), winter-grazed pasture, road verges and track edges. Road verges refer to the grassy embankments found along public highways, whereas track edges refer to the edge habitats bordering rough, un-surfaced tracks with low vehicle use.

In 2010, we concentrated our study on habitats characteristic of the Somerset Levels, focusing on a $5 \mathrm{~km}^{2}$ area south and west of the villages of Cheddar, Draycott and Rodney Stoke (N 51 ${ }^{\circ} 15^{\prime} 17.95^{\prime \prime}$, W $2^{\circ}$ $\left.46^{\prime} 35.50^{\prime \prime}\right)$. We identified four different habitats within this area, which represented all the major habitats present: silage, cattle-grazed pasture, road verges and track edges. Habitat types and their definitions are listed in Table I.

\subsection{Bumblebee sampling techniques}

Bumblebee surveys were carried out on each habitat between the 27th July and 15th August 2009 in the Outer Hebrides. Six replicate sections of each habitat (except summer-grazed pasture) were identified and separated from one another by a minimum distance of $100 \mathrm{~m}$. This distance was constrained by the small sizes of the two study areas; it should be noted that bumblebees will forage over much larger distances than this, so that the same individuals may have visited more than one replicate section. In most instances, agricultural sections were equivalent to a field. Due to access restrictions, we were only able to survey five sections of summer-grazed pasture in the 
Table I. Habitats and their definitions with the range in area of each habitat surveyed.

\begin{tabular}{|c|c|c|c|}
\hline \multirow[t]{2}{*}{ Habitat } & \multirow[t]{2}{*}{ Definition } & \multicolumn{2}{|c|}{ Transect area surveyed $\left(\mathrm{m}^{2}\right)$} \\
\hline & & Outer Hebrides & Somerset Levels \\
\hline Silage & $\begin{array}{l}\text { Outer Hebrides: cultivated land sown with a } \\
\text { grass crop or mixed cereals (barley, } \\
\text { oats and rye) } \\
\text { Somerset Levels: land left to regenerate } \\
\text { to form a natural grass crop/grazed } \\
\text { for a short period after cutting }\end{array}$ & $400-600$ & $1,372-2,568$ \\
\hline Fallow & Cultivated land, not seeded for $\geq 1$ years & $1,200-3,700$ & 0 \\
\hline Pasture & $\begin{array}{l}\text { Outer Hebrides: land grazed throughout the } \\
\text { year by sheep, cattle or both }\end{array}$ & $1,000-3,200$ & $172-2,900$ \\
\hline Cattle-grazed pasture & $\begin{array}{l}\text { Somerset Levels: land grazed by cattle } \\
\text { throughout the year }\end{array}$ & & \\
\hline Winter pasture & $\begin{array}{l}\text { Outer Hebrides: land grazed between } \\
\text { September and May }\end{array}$ & $800-6,000$ & 0 \\
\hline Track edges & $\begin{array}{l}\text { Outer Hebrides: track edges traversing } \\
\text { the machair grassland. No formal } \\
\text { management, often ungrazed during the } \\
\text { summer due to close proximity to } \\
\text { fallow and arable habitats } \\
\text { Somerset Levels: tracks providing farm } \\
\text { access to cattle and silage fields, often } \\
\text { bounded by rhynes (drainage } \\
\text { ditches) and hedges }\end{array}$ & $500-1,300$ & $700-1,300$ \\
\hline Road verges & $\begin{array}{l}\text { Land forming the verge of public highways, } \\
2 \mathrm{~m} \text { either side of the highway } \\
\text { Outer Hebrides: no known management } \\
\text { Somerset Levels: one cut between the } \\
\text { June and July surveys }\end{array}$ & $700-1,700$ & $840-1,100$ \\
\hline
\end{tabular}

Outer Hebrides. In this area, track edges, winter-grazed pasture, fallow and arable habitats were all located on the machair, with summer-grazed pasture located on the inbye land associated with the crofts, and each individual section was surveyed once for foraging bumblebees in August 2009. In 2010, we extended our survey throughout the summer and surveyed each section three times, once in June (9th-15th) and again in July (12th-19th) and August (9th-16th).

Surveys or 'bee walks' were conducted along a series of line transects that were randomly distributed throughout each habitat. The length of transects varied in accordance to the area of each habitat (shown in Table I). In fields (typically sections of pasture or silage), transects were conducted along a zigzag route to ensure that a representative area of the habitat was surveyed. All foraging bumblebees observed within $2 \mathrm{~m}$ on either side of the transects were recorded and identified to species and caste level. The plant species on which bumblebees were observed foraging were also recorded. On the Somerset Levels, silage sections were inaccessible prior to the first cut in June; therefore, these sections were surveyed in July and August only. In the Outer Hebrides, silage is cut later in the year, but only the boundaries of the crop stands were accessible. Consequently, transects were relocated to run parallel with two perimeter edges of the crop forming an ' $\mathrm{L}$ '-shaped transect. All bumblebees observed foraging within $2 \mathrm{~m}$ of the crop side of the transects were recorded, in addition to the forage plant species being utilised. This survey methodology is taken from Redpath et al. (2010) who surveyed bumblebees in similar habitats in 2008 .

In linear habitats (road verges and track edges), the method of bumblebee sampling was adapted from the standard butterfly monitoring protocols 
developed by Pollard (1977). Linear transects were undertaken on randomly selected areas of habitat and walked in one direction along the adjacent road/ track. One side of the linear feature was selected randomly for survey as was the direction transects were walked. Bumblebees observed foraging within $2 \mathrm{~m}$ of the selected side of the transects were recorded as previously described.

All surveys took place in dry weather and when the temperature was above $12^{\circ} \mathrm{C}$ in accordance with the protocols outlined by Carvell (2002). The number and species of any livestock present along a transect were also recorded.

\subsection{Forage plant sampling techniques}

The abundance of bumblebee forage plants in the different habitats was determined by conducting a survey of bumblebee forage plants across the same replicate sections as used for the bee walks using a $0.5 \times 0.5-\mathrm{m}$ quadrat. A total of 200 quadrats were recorded in each habitat. The location of each quadrat was determined using coordinates derived from a random number generator. To reduce potential crop damage, silage sections in the Outer Hebrides were surveyed from transects which ran along two adjacent edges of the crop. In this instance, the number of quadrats per section of silage habitat was proportional to the length of the transect. Although quadrats were placed within the crop, they were limited to the edge of the habitat and therefore may not be representative of whole habitat area. Each habitat section was sampled once in 2009 in the Outer Hebrides and once each month between June and August 2010 on the Somerset Levels to correspond with the monthly bee walks. The inflorescences of all flowers utilised by foraging bumblebees were recorded, as in Redpath et al. (2010).

\subsection{Data analysis}

\subsubsection{Bumblebee dataset}

The effect of habitat on bumblebee abundance was examined using generalised linear models in the statistical software package R 2.11.1 (The R Foundation for Statistical Computing 2010). The abundance of long- and short-tongued foraging bumblebees was examined in separate analyses. Previous authors have found that species with longer tongues tend to be more specialised in their foraging preferences and are often rarer than species with shorter tongues (Goulson and Darvill 2004; Goulson et al. 2005, 2008a; Pywell et al. 2005). For statistical analysis, we grouped together long-tongued species (B. distinguendus, B. muscorum, Bombus pascuorum and Bombus hortorum) and short-tongued species (Bombus lapidarius, Bombus lucorum, Bombus terrestris, Bombus jonellus, Bombus pratorum, Bombus barbutellus and Bombus sylvestris). As very few males were recorded in either study area, species were only subdivided by tongue length for analysis. The Outer Hebrides and Somerset Levels datasets were analysed separately. All models used quasi-Poisson errors except the July shorttongued bumblebee dataset where the data were not over-dispersed and Poisson errors were more appropriate. Date, wind speed and temperature were included in the initial models as covariates and habitat as a fixed factor with non-significant factors eliminated through a step-wise process. Transect area was included as an offset in each model to correct for the differences in the total area surveyed in each habitat and a pseudo- $R^{2}$ value (hereafter referred to as $R^{2}$ values) calculated by correlating the values predicted by each model with the observed data (Zuur et al. 2009). Where the model indicated that habitat was a significant factor, pair-wise comparisons between habitats were conducted to assess differences in bumblebee abundance between habitats within each month.

\subsubsection{Forage plant datasets}

The availability of forage was examined using generalised linear models as described above. One model using quasi-Poisson errors was constructed for the Outer Hebridean dataset, and Gaussian errors were utilised in models for the Somerset Levels. Separate models for June, July and August were created for the Somerset Levels dataset, and $R^{2}$ values were calculated for each model. The effect of habitat was examined in relation to the number of bumblebee forage plant inflorescences per section. Analyses were restricted to known bumblebee forage plants (Goulson and Darvill 2004; Redpath et al. 2010) and included any additional species that we observed bumblebees foraging upon.

The relationship between bumblebee abundance and forage availability was examined using a gener- 
alised linear model for each month of the survey, using quasi-Poisson errors and area as an offset except for the July short-tongued bumblebees in which Poisson errors were utilised.

\section{RESULTS}

\subsection{Habitat and bumblebee abundance}

\subsubsection{Outer Hebrides}

A total of 494 foraging bumblebees belonging to five species were recorded across all habitat types in 2009 (Table II). All species known to be found within the Outer Hebrides study area were recorded foraging in at least one of the habitats surveyed.

The abundance of long-tongued bumblebees varied significantly between habitat types $\left(\chi_{5}^{2}=12.35, P=0.03\right.$; Table III; Figure 1a). Following model simplification where temperature and wind speed were removed, only habitat remained in the final model, explaining $81 \%$ of variation. Significantly fewer long- tongued bumblebees were observed on pasture than winter-grazed pasture (Table III). Comparing the median number of bumblebees recorded on each habitat highlights that nine times more bumblebees were supported by pasture which was only grazed in the winter, rather than pasture subject to year-round grazing. The abundance of short-tongued bumblebees also varied with habitat type (Figure 1b), but the relationship was not significant $\left(\chi^{2}=5.25_{5}, P=0.386\right)$.

\subsubsection{Somerset Levels}

A total of 439 foraging bumblebees of nine species were recorded across all habitats in the study area between June and August (Table II). Early in the season abundance was low but increased fivefold in July when flower abundance was at its peak.

Differences in long-tongued bumblebee abundance between habitats in June were small and not significant $\left(\chi_{2}^{2}=0.02, P=\right.$ 0.992, Table IIa). Wind speed correlated

Table II. The percentage of each bumblebee species observed foraging on all habitats in the Outer Hebrides in 2009 (total $n=494$ ) and throughout the field season on the Somerset Levels in 2010 (total $n=439$ ).

$\%$ Total bumblebees

Species $\quad$ Outer Hebrides

Somerset Levels

\begin{tabular}{lll}
\hline June & July & August
\end{tabular}

B. lapidarius

B. lucorum/terrestris $^{\mathrm{a}, \mathrm{b}}$

B. muscorum

B. pascuorum

B. distinguendus

B. pratorum

B. sylvestris

B. hortorum

B. jonellus

B. barbutellus

Unidentified

$\begin{array}{rr}0 & 27 \\ 29 & 3 \\ 61 & \\ 0 & 2 \\ 7 & \\ 0 & \\ 0 & \\ 3 & \\ <1 & \\ 0 & \\ 0 & \end{array}$

27
33
0
26
0
11
3
0
0
0
0

$\begin{array}{rr}53 & 43 \\ 26 & 8 \\ 0 & 0 \\ 14 & 49 \\ 0 & 0 \\ 0 & 0 \\ <1 & 0 \\ 5 & 0 \\ <1 & 0 \\ <1 & 0 \\ <1 & 0\end{array}$

${ }^{a}$ Due to the difficulty in distinguishing the workers of these species from one another, individuals of both species were recorded collectively

${ }^{\mathrm{b}}$ Only B. lucorum is present in the Outer Hebrides study area 
Table III. The association between habitat on long-tongued bumblebee abundance in the Outer Hebrides.

\begin{tabular}{|c|c|c|c|c|c|c|c|c|c|c|}
\hline & \multicolumn{2}{|c|}{ Arable } & \multicolumn{2}{|l|}{ Fallow } & \multicolumn{2}{|c|}{ Pasture } & \multicolumn{2}{|c|}{ Road verges } & \multicolumn{2}{|c|}{ Track edges } \\
\hline & $t$ & $p$ & $t$ & $p$ & $t$ & $p$ & $t$ & $p$ & $t$ & $p$ \\
\hline Fallow & 1.058 & 0.299 & & & & & & & & \\
\hline Pasture & 0.085 & 0.932 & -1.764 & 0.088 & & & & & & \\
\hline Road verges & 1.149 & 0.260 & 0.315 & 0.755 & 1.871 & 0.072 & & & & \\
\hline Track edges & 1.246 & 0.223 & 0.584 & 0.564 & 1.985 & 0.057 & 0.276 & 0.785 & & \\
\hline Winter grazed & 1.386 & 0.176 & 1.198 & 0.241 & 2.417 & 0.022 & 0.657 & 0.516 & 0.252 & 0.803 \\
\hline
\end{tabular}

The $t$ and $p$ values are derived from pair-wise comparisons made between each of habitat. Negative $t$ values show that the habitat listed along the rows of the table supported fewer long-tongued bumblebees than the habitat listed as the column heading and vice versa. Numbers in bold refer to significant results at the $<0.05$ significance level

negatively with the abundance of this group in June $\left(\chi_{1}^{2}=4.39, P=0.036\right)$, with the highest abundances recorded when wind speeds were $<1 \mathrm{~m} / \mathrm{s}$.

Habitat was a significant predictor of longtongued bumblebee abundance in July $\left(\chi_{3}^{2}=\right.$ 42.95, $P<0.0001$; Figure $2 b$ ), with the model explaining $85 \%$ of the variation observed. Road verges and track edges supported significantly more long-tongued bumblebees than either cattle-grazed pasture or silage fields, with the median number of bumblebees recorded on each habitat illustrating that nine times more bumblebees were observed on off-farm habitats (Table IV; Figure 2b). Temperature was also a significant predictor of abundance $\left(\chi_{1}^{2}=9.27, P=\right.$ $0.002)$, with higher temperatures corresponding to lower abundance. No long-tongued bumblebees were recorded on surveys where the temperature was recorded as $25^{\circ} \mathrm{C}$ or above, with all observations made when the temperature ranged from $21.6^{\circ} \mathrm{C}$ to $24.9^{\circ} \mathrm{C}$.

The association between habitat and shorttongued bumblebee abundance in July contrasted to long-tongued bumblebee abundance. Cattle-grazed pasture supported 50-60\% higher densities of foraging short-tongued bumblebees than road verges or track edges. Twice as many short-tongued bumblebees were recorded on silage than either off-farm habitat $\left(\chi_{3}^{2}=22.65, P=<0.0001\right.$; Figure $3 \mathrm{~b}$; Table IV), but only $35 \%$ of the observed variation was explained by this model. Higher wind speeds and temperatures were associated with lower numbers of this group $\left(\chi_{1}^{2}=10.83, P=0.001\right.$; $\left.\chi_{1}^{2}=7.44, P=0.006\right)$.

Overall, the abundance of both long- and short-tongued bumblebees declined more than fivefold between July and August, with just 51 individuals recorded across all habitats in August. Track edges supported the greatest densities of long-tongued bumblebees, with $39 \%$ more than on silage or cattle-grazed pasture $\left(\chi_{3}^{2}=10.96, P=0.012\right.$; Figure $\left.2 \mathrm{c}\right)$. Again, higher temperatures were associated with lower abundance of this group $\left(\chi_{1}^{2}=\right.$ 10.96, $P=0.038$ ).

There was little variation in short-tongued bumblebee abundance in August (Figure 3c), and habitat had no significant association with the abundance of this group $\left(\chi_{3}^{2}=5.76\right.$, $P=0.124$ ). Wind speed was negatively correlated with abundance and was the only significant explanatory for short-tongued bumblebee abundance in this month $\left(\chi_{1}^{2}=\right.$ 3.84, $P=0.050)$.

\subsection{Habitat and the availability of bumblebee forage plants}

The abundance of bee-flower inflorescences varied between habitats in the Outer Hebrides, with forage availability greatest on road verges, unmanaged track edges and 

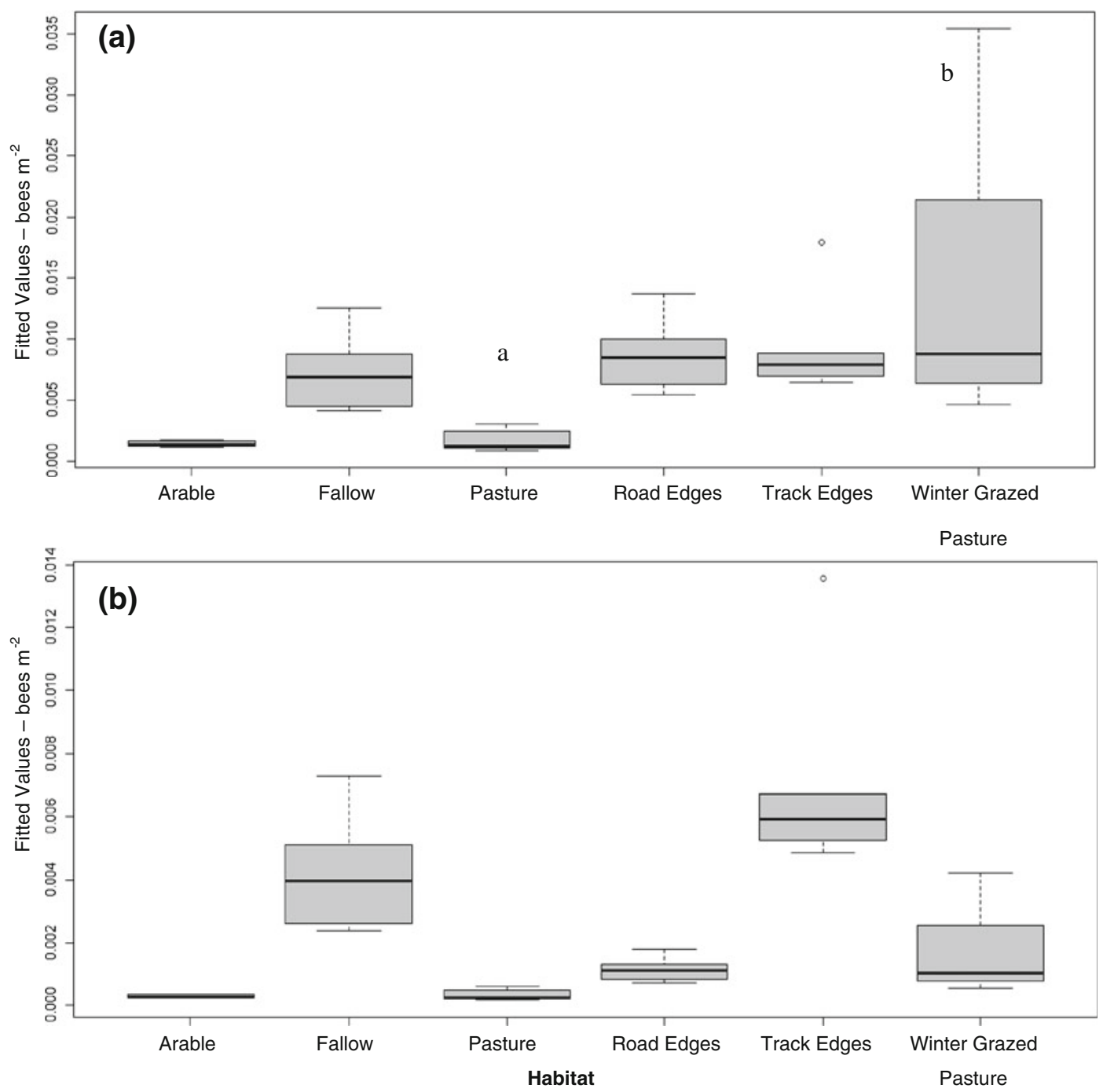

Figure 1. a, b Box plots showing fitted values from the model for long-tongued bumblebee abundance (a) and the model for short-tongued bumblebee abundance (b) across six different habitats in the Outer Hebrides. Boxes represent the location of the middle $50 \%$ of the data, and the whiskers indicate the interquartile range of the data. $a$ and $b$ denote significant differences between habitats.

winter-grazed pasture $\left(\chi_{5}^{2}=23.2, P=0.0003\right.$; Table V). Arable and summer-grazed pasture had the lowest densities of bumblebee forage with fewer than $10 \%$ of total bee-flower inflorescences recorded in each habitat, less than a third of the number of inflorescences found in road verges. Unsurprisingly, arable and summer-grazed areas were also the habitats where the lowest long-tongued bumblebee densities were recorded. Interestingly, fallow habitats contained significantly fewer inflorescences than road verges (Table V), yet supported equal numbers of foraging long-tongued bumblebees. Although fallow contained few bee-flowers, it 

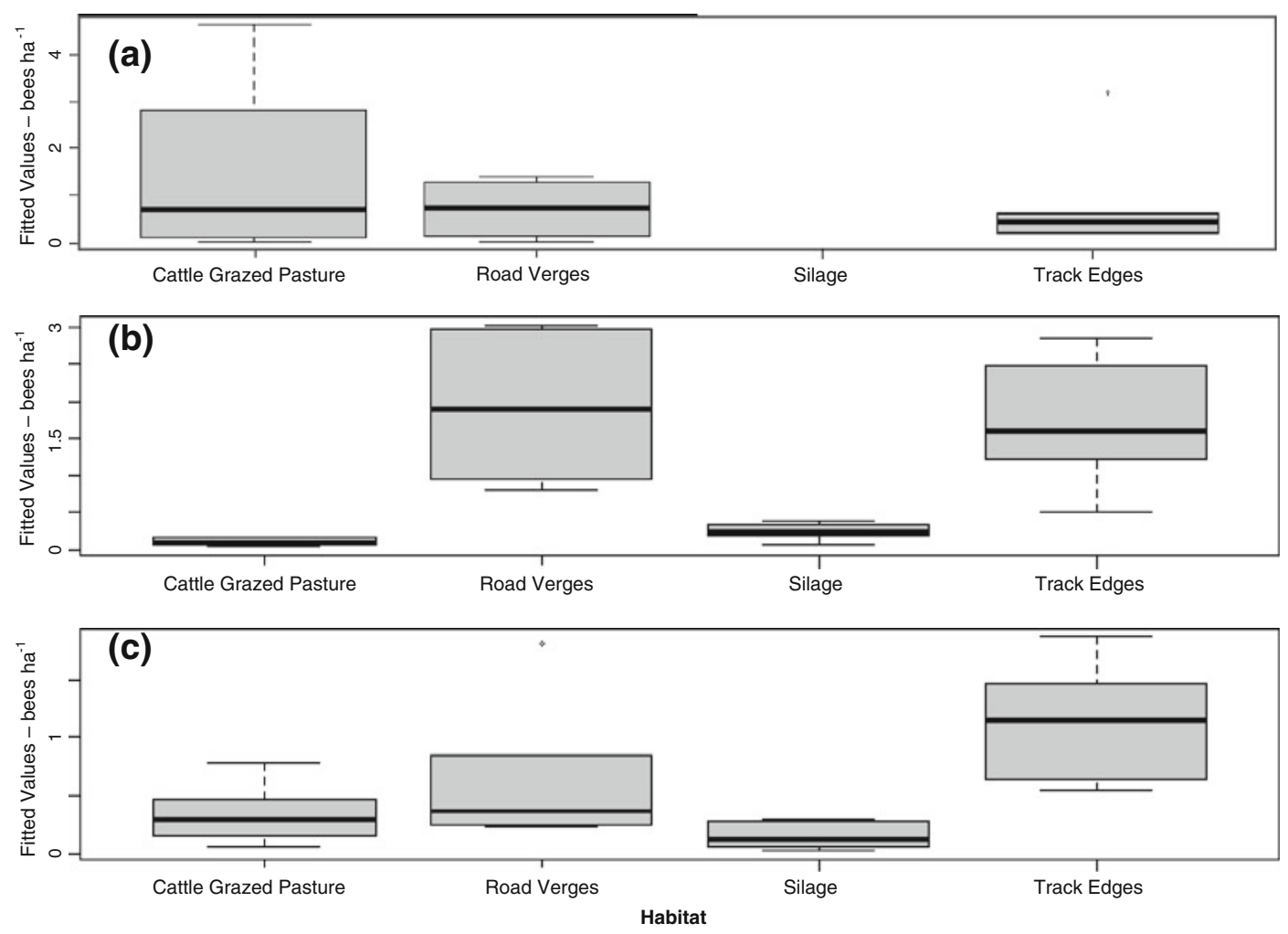

Figure 2. a-c Box plots showing fitted values from the models for long-tongued bumblebee abundance across four different habitats in the Somerset Levels. a The data for June, b July and c August 2010. Boxes represent the location of the middle $50 \%$ of the data, and the whiskers indicate the interquartile range of the data.

had the highest abundances of both Senecio jacobeae and Cirsium vulgare, which were two of the most frequently visited plant species by long-tongued bumblebees.

On the Somerset Levels, forage availability was similar between habitats in June $\left(\chi_{2}^{2}=3.80\right.$, $P=0.150$; Figure 4a). In July, road verges supported significantly fewer bee-flowers than either silage or cattle-grazed pasture $(t=2.19$, $P=0.041, t=-2.83, P=0.011$ respectively; Figure $4 \mathrm{~b}$ ), with $<50 \%$ of inflorescences present in either farmed habitat. No other significant differences were identified between habitats in July. Habitat was not a significant predictor of forage plant availability in August $\left(\chi_{3}^{2}=4.99, P=0.173\right)$.

\subsection{The relationship between bumblebee abundance and forage availability}

Bee-flower inflorescence density was a significant predictor of long-tongued bumblebee abundance in the Outer Hebrides $\left(\chi_{1}^{2}=4.75, P=\right.$ 0.029 ), explaining $64 \%$ of the variation observed. The variation in abundance of bee-flower inflorescences broadly reflects the distribution of long-tongued bumblebees in the Outer Hebrides. However, the model explains considerably less variation than the model that used habitat as the explanatory variable, suggesting that habitat is a better predictor of long-tongued bumblebee abundance. Forage availability was not a significant predictor of 
short-tongued bumblebee abundance $\left(\chi_{1}^{2}=\right.$ $0.41, P=0.524)$.

On the Somerset Levels, the relationship between forage availability and bumblebee abundance varied between months and between long- versus short-tongued bumblebees. There was a positive association between the number of inflorescences and long-tongued bumblebee abundance in both June and August $\left(\chi_{1}^{2}=27.61\right.$, $P=<0.0001 ; \chi_{1}^{2}=4.28, P=0.039$, respectively), but not in July $\left(\chi_{1}^{2}=1.01, P=0.906\right)$, which may be due to a reduction in the number of inflorescences suitable for long-longed species. Similarly, there was a positive association between the number of inflorescences and short-tongued bumblebees in July and August $\left(\chi_{1}^{2}=19.22, P=<0.0001 ; \chi_{1}^{2}=10.90, P=0.001\right)$, but not in June $\left(\chi_{1}^{2}=0.22, P=0.640\right)$. In general, habitat type was a better predictor of both longand short-tongued bumblebee abundances than numbers of flowers.

\subsection{Bumblebee forage plant choices}

A total of ten flowering plant species were utilised by foraging bumblebees throughout the study in the Outer Hebrides (Table VI). Of these, Centaurea nigra, $S$. jacobeae and $C$. vulgare were the most frequently visited and together accounted for over $85 \%$ of all foraging visits recorded. C. nigra was most frequently recorded on winter-grazed pasture $(48 \%$ of records) and road verges ( $41 \%$ of records) and accounted for the greatest proportion of foraging visits made by $B$. distinguendus and $B$. muscorum (58\% and 50\%, respectively). The density of $C$. nigra was a significant predictor of long-tongued bumblebee density $\left(\chi_{1}^{2}=11.10\right.$, $\left.P=0.0008, R^{2}=0.80\right)$, but not of short-tongued bumblebees $\left(\chi_{1}^{2}=2.11, P=0.146\right)$. The abundance of $S$. jacobeae and $C$. vulgare had no significant effect on either long- or shorttongued bumblebee abundance.

In contrast to the Outer Hebrides, few visits were made to the Asteraceae by foraging bumblebees on the Somerset Levels (Table VI). Trifolium repens was particularly important to 

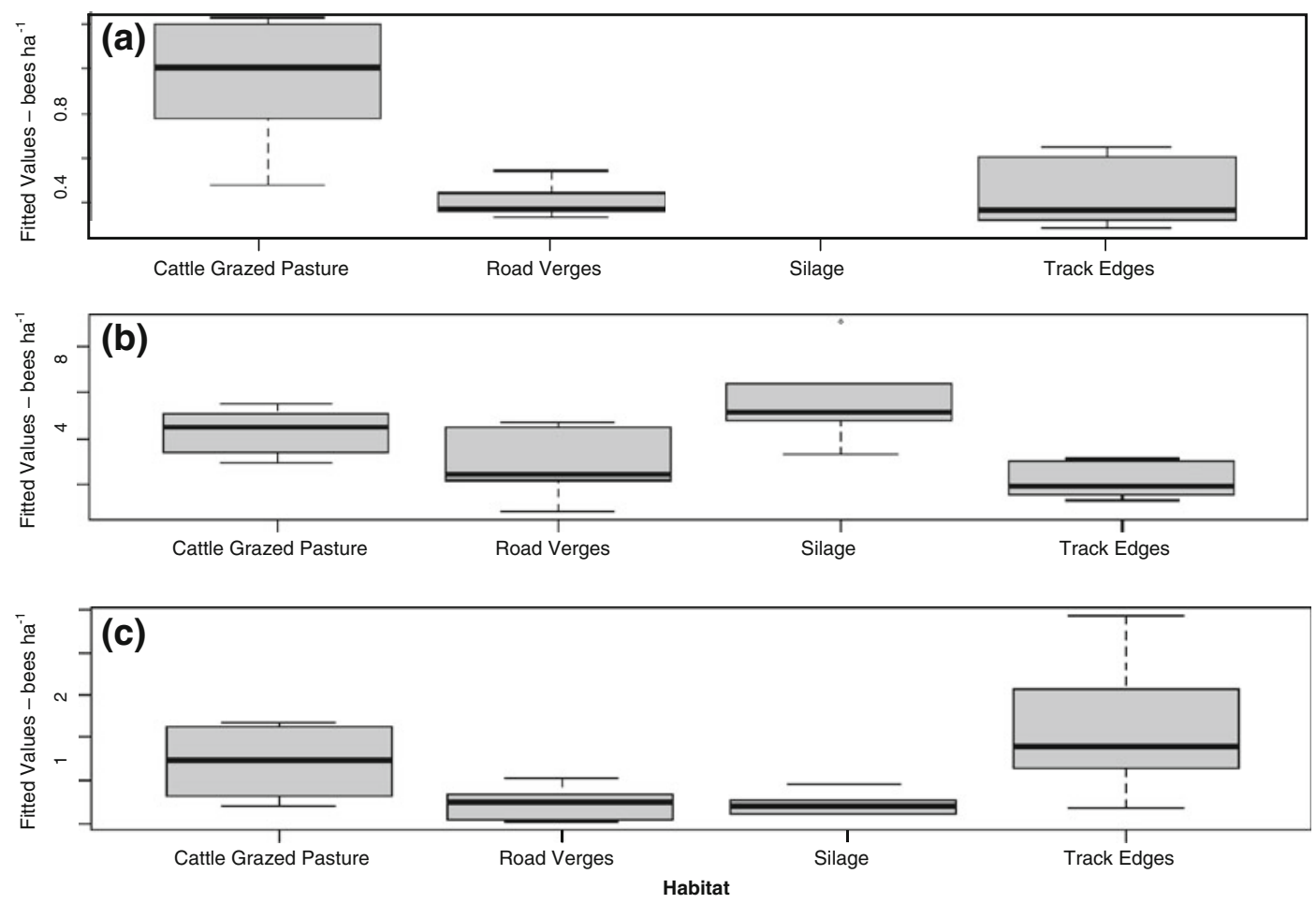

Figure 3. a-c Box plots showing fitted values from the models for short-tongued bumblebee abundance across four different habitats in the Somerset Levels. a The data for June, b July and c August 2010. Boxes represent the location of the middle $50 \%$ of the data, and the whiskers indicate the interquartile range of the data.

short-tongued species and was the most predictor of $B$. lapidarius abundance in July frequently utilised flower species in June and $\left(\chi_{1}^{2}=10.40, P=0.001\right)$. Cattle-grazed pasture July, accounting for $90 \%$ and $60 \%$ of all and silage fields supported the greatest abunforaging visits, respectively. The abundance of dances of $T$. repens throughout the survey this plant species was also a significant period. Although members of the Fabaceae

Table V. The association between habitat and forage plant abundance in the Outer Hebrides.

\begin{tabular}{|c|c|c|c|c|c|c|c|c|c|c|}
\hline & \multicolumn{2}{|l|}{ Arable } & \multicolumn{2}{|l|}{ Fallow } & \multicolumn{2}{|c|}{ Pasture } & \multicolumn{2}{|c|}{ Road verges } & \multicolumn{2}{|c|}{ Track edges } \\
\hline & $t$ & $p$ & $t$ & $p$ & $t$ & $p$ & $t$ & $p$ & $t$ & $p$ \\
\hline Fallow & 0.788 & 0.437 & & & & & & & & \\
\hline Pasture & -0.193 & 0.849 & -0.974 & 0.339 & & & & & & \\
\hline Road verges & 3.079 & 0.005 & 2.486 & 0.020 & 3.200 & 0.004 & & & & \\
\hline Track edges & 2.497 & 0.019 & 1.833 & 0.078 & 2.639 & 0.014 & -0.729 & 0.47 & & \\
\hline Winter grazed & 2.428 & 0.022 & 1.757 & 0.091 & 2.572 & 0.016 & -0.811 & 0.425 & -0.083 & 0.935 \\
\hline
\end{tabular}

The $t$ and $p$ values are derived from pair-wise comparisons made between each of habitat. Negative $t$ values show that the habitat listed along the rows of the table supported significantly fewer bumblebees than the habitat listed as the column heading and vice versa. Numbers in bold refer to significant results at the $<0.05$ significance level 

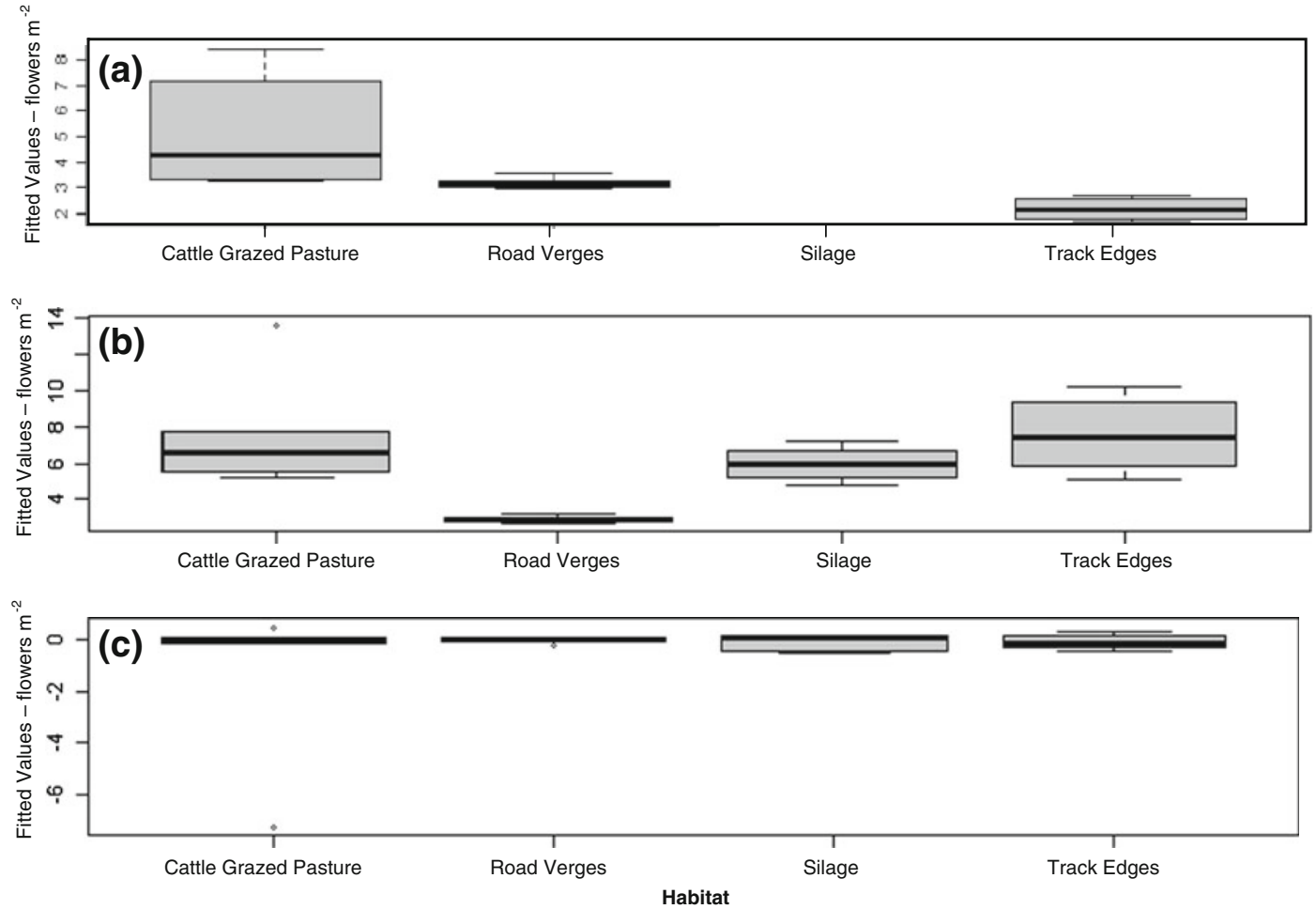

Figure 4. a-c Box plots showing fitted values from the models for the abundance of bumblebee forage plants on four different habitats in the Somerset Levels. a The data for June, b July and c August 2010. Boxes represent the location of the middle $50 \%$ of the data, and the whiskers indicate the interquartile range of the data.

were also important for long-tongued bumblebees in June, this group of bumblebees was predominantly recorded foraging on Rubus fruticosus and Epilobium spp. in July and August. These plants were both confined to road verges and track edges

\section{DISCUSSION}

\subsection{The effect of habitat on bumblebee abundance and the availability of key bumblebee forage plants}

Landscape heterogeneity has been shown to promote bumblebee abundance and diversity (Charman 2007; Rundlöf et al. 2008), as well as species richness for a range of other taxa, in agricultural landscapes (Weibull et al. 2003).
We found that both agricultural and adjacent non-agricultural habitats were utilised by foraging bumblebees in both study areas, but offfarm habitats were of greater importance to long-tongued species than the adjacent agricultural habitats. Similarly, Mänd et al. (2002) found greater diversity of foraging bumblebees within non-agricultural habitats adjacent to farmland in Estonia. Track edges and road verges are outside the direct influence of farm management practices, although they are still subject to indirect influences from the adjacent agricultural land.

However, these non-agricultural habitats are increasingly important for providing additional sources of forage and may increase the abundance and diversity of bumblebee populations if managed correctly. For example, in Kansas, USA, Hopwood (2008) 
Table VI. The flower species visited by foraging bumblebees in the Outer Hebrides and the Somerset Levels.

\begin{tabular}{|c|c|c|c|c|c|c|c|c|c|}
\hline \multirow{3}{*}{$\begin{array}{l}\text { Flower } \\
\text { species }\end{array}$} & \multirow[t]{3}{*}{ Family } & \multirow{2}{*}{\multicolumn{2}{|c|}{ Outer Hebrides }} & \multicolumn{6}{|c|}{ Somerset Levels } \\
\hline & & & & \multicolumn{2}{|l|}{ June } & \multicolumn{2}{|l|}{ July } & \multicolumn{2}{|c|}{ August } \\
\hline & & $\begin{array}{l}\text { Long } \\
(\%)\end{array}$ & $\begin{array}{l}\text { Short } \\
(\%)\end{array}$ & Long (\%) & $\begin{array}{l}\text { Short } \\
(\%)\end{array}$ & $\begin{array}{l}\text { Long } \\
(\%)\end{array}$ & $\begin{array}{l}\text { Short } \\
(\%)\end{array}$ & $\begin{array}{l}\text { Long } \\
(\%)\end{array}$ & $\begin{array}{l}\text { Short } \\
(\%)\end{array}$ \\
\hline $\begin{array}{l}\text { Centaurea } \\
\text { nigra }\end{array}$ & Asteraceae & 49 & 42 & - & - & - & - & - & - \\
\hline $\begin{array}{l}\text { Senecio } \\
\text { jacobeae }\end{array}$ & Asteraceae & 19 & 47 & - & - & - & - & - & - \\
\hline $\begin{array}{l}\text { Cirsium } \\
\text { vulgare }\end{array}$ & Asteraceae & 15 & 1 & 0 & 0 & 11 & 5 & 16 & 4 \\
\hline $\begin{array}{l}\text { Yellow } \\
\text { composite }\end{array}$ & Asteraceae & 5 & 1 & - & - & - & - & - & - \\
\hline $\begin{array}{l}\text { Cirsium } \\
\text { arvense }\end{array}$ & Asteraceae & 1 & 1 & 0 & 2 & 6 & 4 & 0 & 0 \\
\hline $\begin{array}{c}\text { Arctium } \\
\text { lappa }\end{array}$ & Asteraceae & - & - & 0 & 0 & 4 & $<1$ & 0 & 0 \\
\hline $\begin{array}{l}\text { Trifolium } \\
\text { pratense }\end{array}$ & Fabaceae & 6 & 0 & 19 & 0 & 2 & $<1$ & 8 & 0 \\
\hline $\begin{array}{l}\text { Trifolium } \\
\text { repens }\end{array}$ & Fabaceae & 1 & 2 & 0 & 90 & 7 & 60 & 8 & 42 \\
\hline Vicia cracca & Fabaceae & $<1$ & $<1$ & 0 & 0 & 0 & 0 & 0 & 0 \\
\hline Vicia ervilia & Fabaceae & - & - & 44 & 2 & 0 & 0 & 0 & 0 \\
\hline $\begin{array}{l}\text { Anthyllis } \\
\quad \text { vulneraria }\end{array}$ & Fabaceae & 1 & 6 & - & - & - & - & - & - \\
\hline $\begin{array}{l}\text { Lathyrus } \\
\text { pratensis }\end{array}$ & Fabaceae & - & - & 6 & 0 & 0 & 0 & 0 & 0 \\
\hline $\begin{array}{l}\text { Odontites } \\
\text { verna }\end{array}$ & Scrophulariaceae & 2 & $<1$ & - & - & - & - & - & - \\
\hline $\begin{array}{c}\text { Symphytum } \\
\text { officinale }\end{array}$ & Boraginaceae & - & - & 25 & 2 & 4 & 0 & 4 & 0 \\
\hline $\begin{array}{l}\text { Rubus } \\
\text { fruticosus }\end{array}$ & Rosaceae & - & - & 0 & 4 & 41 & 13 & 12 & 8 \\
\hline $\begin{array}{l}\text { Lamium } \\
\text { album }\end{array}$ & Lamiaceae & - & - & 6 & 0 & 2 & 0 & 8 & 0 \\
\hline $\begin{array}{l}\text { Epilobium } \\
\text { spp. }\end{array}$ & Onagraceae & - & - & 0 & 0 & 21 & 17 & 28 & 42 \\
\hline $\begin{array}{l}\text { Hypericum } \\
\text { spp. }\end{array}$ & Clusiaceae & - & - & 0 & 0 & 2 & 0 & 0 & 0 \\
\hline $\begin{array}{l}\text { Dipsacus } \\
\text { fullonum }\end{array}$ & Dipsacaceae & - & - & 0 & 0 & 0 & $<1$ & 16 & 0 \\
\hline $\begin{array}{l}\text { Solanum } \\
\text { dulcamara }\end{array}$ & Solanaceae & - & - & 0 & 0 & 0 & 0 & 0 & 4 \\
\hline
\end{tabular}

The number of visits made by long and short-tongued bumblebees to each species is shown as percentages

demonstrated that bumblebee species richness and abundance were significantly greater on road verges that had been restored to native vegetation rather than verges where non-native species dominated.
On the Somerset Levels, cattle-grazed fields and silage provided an abundance of key forage plants for short-tongued bumblebee species compared to the other available habitats. Where silage is cut early in the 
season, this management practice creates important foraging habitats for short-tongued species for a considerable proportion of the bumblebee's flight period. Properly managed grazing and cutting regimes may therefore benefit some bumblebees. Indeed, Carvell (2002) also identified cattle grazing as a beneficial management tool for promoting bumblebee abundance in grassland landscapes in southern England and highlighted the importance of extensive cattle grazing between April and September. In our study, bumblebee abundance fell dramatically in August, in line with a decline in forage plants. The availability and abundance of key bumblebee forage plants throughout the flight season are crucial for maintaining diverse bumblebee assemblages (Bäckman and Tiainen 2002; Westphal et al. 2006; Goulson et al. 2008 b); therefore, additional sources of forage are required in late summer to support the final stages of colony development.

\subsection{Bumblebee floral resource use}

In accordance with previous studies (e.g. Goulson and Darvill 2004; Redpath et al. 2010), our data show that bumblebees utilise a few key forage plant species rather than particularly diverse floral assemblages. Of the ten flowering plant species that bumblebees were recorded using in the Outer Hebrides, only three made up $85 \%$ of all foraging visits. C. nigra was the most frequented by longtongued bumblebees, and its availability within the landscape was related to the abundance of this group. $C$. nigra is known to be an important resource for both $B$. distinguendus and $B$. muscorum (Benton 2006).

A large proportion of the bumblebees recorded on the Somerset Levels were shorttongued species. Bumblebees in this group are more general in their dietary requirements than longer-tongued species and exploit a wider range of floral resources (Goulson and Darvill 2004; Goulson et al. 2005), including nonnative and cultivated flowers found in urban areas (Goulson et al. 2002). T. repens was a particularly important source of forage for shorttongued bumblebees early in the season. This species was predominantly located on cattlegrazed pasture and silage fields, therefore accounting for the strong association between shorttongued bumblebees and these farmland habitats.

\subsection{Implications for conservation management}

Both this study and that by Redpath et al. (2010) highlight the negative impact on bumblebee populations of the increasingly intensive livestock production methods employed in the Outer Hebrides. Management of winter-grazed pasture, where livestock are absent from lowland grassland areas for a period during the summer allowing the sward to regenerate, reflects historical grazing regimes. Our data demonstrate that summer-grazed areas in this region have fewer flowers and bumblebees. In contrast, in the cattle grazing systems typical of lowland regions grazing throughout the summer is an efficient means of providing bumblebee forage for a lengthy period during the early-mid flight period due to the prevalence of $T$. repens in these habitats.

The rural road network may provide important habitats for farmland biodiversity (Pauwels and Gulinck 2000), and the results of our study suggest that road verges and track edges are of greater value to long-tongued bumblebees than farmed habitats, particularly in intensively managed agricultural landscapes. With the decline of pollinators and the potential negative impacts on the ecosystems services that they provide, the use of these off-farm habitats for supporting flower-visiting insects may be increasingly important. Indeed, road verges have the potential to be managed for the benefit of a range of other insects in addition to bees, including Lepidoptera and Coleoptera (e.g. Landis et al. 2000; Saarinen et al. 2005; Noordijk et al. 2009; Decourtye et al. 2010).

The value of track edges and road verges to long-tongued bumblebees and other pollinators is likely to be applicable to other regions, both within the UK and Europe, where 
intensive agriculture limits landscape heterogeneity and the availability of suitable forage material. As road verges are found on nonagricultural land, they fall outside the scope of agri-environment scheme payments to encourage beneficial management practices. We therefore suggest that road verges be integrated into local land management plans in areas characterised by intensive agricultural practices to ensure suitable management is maintained for bumblebees and other invertebrates throughout the year.

\section{ACKNOWLEDGEMENTS}

We thank Scottish Natural Heritage for funding this research. We would also like to thank all the landowners in the Outer Hebrides and the Somerset Levels who allowed us access to their land. We also thank the three anonymous referees for comments on the manuscript.

Utilisation, par les bourdons, des habitats noncultivés dans les paysages agricoles: implications dans des aménagements à but de conservation.

\section{Bombus / approvisionnement / utilisation des habitats / bord de route / pâturage}

\section{Die Nützlichkeit von Habitaten außerhalb der landwirtschaftlichen Flächen in Agrargebieten für sammelnde Hummeln: Bedeutung für den Artenschutz}

\section{Bombus / Sammeln / Habitatnutzung / Straßenrand / Weide}

\section{REFERENCES}

Bäckman, J.-P.C., Tiainen, J. (2002) Habitat quality of field margins in a finish farmland area for bumblebees (Hymenoptera: Bombus and Psithyrus). Agr. Ecosyst. Environ. 89, 53-68

Benton, T. (2006) Bumblebees: the Natural History and Identification of the Species Found in Britain. Harper Collins, London
Carvell, C. (2002) Habitat use and conservation of bumblebees (Bombus spp.) under different grassland management regimes. Biol. Conserv. 103, 33-49

Carvell, C., Roy, D.B., Smart, S.M., Pywell, R.F., Preston, C.D., Goulson, D. (2006) Declines in forage availability for bumblebees at a national scale. Biol. Conserv. 132, 481-489

Chamberlain, D.E., Fuller, R.J., Bunce, R.G.H., Duckworth, J.C., Shrubb, M. (2000) Changes in the abundance of farmland birds in relation to the timing of agricultural intensification in England and Wales. J. Appl. Ecol. 37, 771-788

Charman, T. (2007) Ecology and conservation genetics of Bombus distinguendus, the Great Yellow Bumblebee. Ph.D. thesis, University of Cambridge

Croxton, P.J., Carvell, C., Mountford, J.O., Sparks, T.H. (2002) A comparison of green lanes and field margins as bumblebee habitat in an arable landscape. Biol. Conserv. 107, 365-374

Decourtye, A., Mader, E., Desneux, N. (2010) Landscape scale enhancement of floral resources for honey bees in agro-ecosystems. Apidologie. 41, 264-277

Goulson, D. (2003) Bumblebees - behaviour and ecology. Oxford University Press, Oxford

Goulson, D., Darvill, B. (2004) Niche overlap and diet breadth in bumblebees; are rare species more specialized in their choice of flowers? Apidologie. 35, 55-63

Goulson, D., Hanley, M.E., Darvill, B., Ellis, J.S. (2006) Biotope associations and the decline of bumblebees (Bombus spp.). J. Insect Conserv 10, 95-103

Goulson, D., Hanley, M.E., Darvill, B., Ellis, J.S., Knight, M.E. (2005) Causes of rarity in bumblebees. Biol. Conserv. 122, 1-8

Goulson, D., Hughes, W.O.H., Derwent, L.C., Stout, J.C. (2002) Colony growth of the bumblebee, Bombus terrestris, in improved and conventional agricultural and suburban habitats. Oecologia. 130, 267-273

Goulson, D., Lye, G.C., Darvill, B. (2008a) Decline and conservation of bumble bees. Annu. Rev. Entomol. 53, 191-208

Goulson, D., Lye, G.C., Darvill, B. (2008b) Diet breadth, coexistence and rarity in bumblebees. Biodivers. Conserv. 17, 3269-3288

Hopwood, J.L. (2008) The contribution of roadside grassland restorations to native bee conservation. Biol. Conserv. 141, 2632-2640

Landis, D.A., Wratten, S.D., Gurr, G.M. (2000) Habitat management to conserve natural enemies of arthropod pests in agriculture. Annu. Rev. Entomol. 45, 175-201

Love, J. (2003) Machair-Scotland's Living Landscapes. Scottish Natural Heritage, Battleby

Mänd, M., Mänd, R., Williams, I.H. (2002) Bumblebees in the agricultural landscape of Estonia. Agr. Ecosyst. Environ. 89, 69-76

Natural England (2010) Information available to view at: http://www.naturalengland.org.uk/ourwork/farming/ 
funding/closedschemes/esa/somersetlevelsand moors.aspx

Noordijk, J., Delille, K., Schaffers, A.P., Sýkora, K.V. (2009) Optimizing grassland management for flower-visiting insects in roadside verges. Biol. Conserv. 142, 2097-2103

Pauwels, G., Gulinck, H. (2000) Changing minor rural road networks in relation to landscape sustainability and farming practices in West Europe. Agr. Ecosyst. Environment. 77, 95-99

Pollard, E. (1977) A method for assessing changes in abundance of butterflies. Biol. Conserv. 12, 115-134

Pywell, R.F., Warman, E.A., Carvell, C., Sparks, T.H., Dicks, L.V., Bennett, D., Wright, A., Critchley, C.N. R., Sherwood, A. (2005) Providing foraging resources for bumblebees in intensively farmed landscapes. Biol. Conserv. 121, 479-494

Redpath, N., Osgathorpe, L.M., Park, K., Goulson, D. (2010) Crofting and bumblebee conservation: the impact of land management practices on bumblebee populations in northwest Scotland. Biol. Conserv. 143, 492-500

Robinson, R.A., Sutherland, W.J. (2002) Post-war changes in arable farming and biodiversity in Great Britain. J. Appl. Ecol. 39, 157-176

Rundlöf, M., Nilsson, H., Smith, H.G. (2008) Interacting effects of farming practice and land- scape context on bumble bees. Biol. Conserv. 141, 417-426

Saarinen, K., Valtonen, A., Jantunen, J., Saarnio, S. (2005) Butterflies and diurnal moths along road verges: does road type affect diversity and abundance? Biol. Conserv. 123, 403-412

Stoate, C., Boatman, N.D., Borralho, R.J., Rio Carvalho, C., de Snoo, G.R., Eden, P. (2001) Ecological impacts of arable intensification in Europe. J. Environ. Manag. 63, 337-365

The R Foundation for Statistical Computing (2010) R version 2.11.1. (2010-05-31)

Weibull, A., Östman, Ö., Granqvist, A. (2003) Species richness in agroecosystems: the effect of landscape, habitat and farm management. Biodiver. Conserv. 12, 1335-1355

Westphal, C., Steffan-Dewenter, I., Tscharntke, T. (2006) Foraging trip duration of bumblebees in relation to landscape-wide resource availability. Ecol. Entomol. 31, 389-394

Williams, P.H., Osborne, J.L. (2009) Bumblebee vulnerability and conservation world-wide. Apidologie $\mathbf{4 0}$ (3), 367-387

Zuur, A.F., Ieno, E.N., Walker, N.J., Savaliey, A.A., Smith, G.M. (2009) Mixed Effects Models and Extensions in Ecology with R. Springer Science and Business Media, New York 